\title{
Dos imágenes del arzobispo de Guadalajara Francisco Orozco y Jiménez
}

Julia Preciado Zamora

Este artículo examina la (auto)construcción de la figura eclesiástica de Francisco Orozco y Jiménez, arzobispo de Guadalajara de 1912 a 1936. Durante su vida coexistieron dos imágenes contrastantes en torno a su persona: la que él mismo creó y la que le construyeron los gobiernos civiles anticlericales. Al principio de su periodo como arzobispo, su imagen juvenil fue una de sus mejores armas; al final, la estampa de anciano fue un escudo que lo protegió de los ataques de las autoridades gubernamentales. Las fotografías como documento histórico son la principal fuente de información de este análisis, basado en los supuestos teóricos de Erving Goffman y Peter Burke sobre cómo los individuos se presentan ante la sociedad y en el concepto de tradición concebido por Eric Hobsbawm.

PALABRAS CLAVE: Iglesia católica, arzobispo, imagen, fotografía, Guadalajara

\section{Two Images of Francisco Orozco y Jiménez, Archbishop of Guadalajara}

This article examines the (self)construction of the ecclesiastical image of Francisco Orozco y Jiménez, archbishop of Guadalajara from 1912 to 1936. During his lifetime two contrasting images of Orozco y Jiménez coexisted: the one he created himself and the one that several anticlerical and civil governments drew of him. At the beginning of his rule one of his best weapons was the image of the young archbishop; at the end, his old man's looks shielded him effectively of the attacks from the civil authorities. Photographs as historical documents are the main source of information in this analysis, based on the theoretical assumptions of Erving Goffman and Peter Burke on how individuals portray themselves in society, and the concept of tradition conceived by Eric Hobsbawm.

KEYWORDS: Catholic Church, archbishop, image, photograph, Guadalajara

Julia Preciado Zamora: Centro de Investigaciones y Estudios Superiores en Antropología Social-Occidente,

Guadalajara, Jalisco, México

julia.preciado@gmail.com

Desacatos, núm. 40, septiembre-diciembre 2012, pp. 79-96

Recepción: 9 de septiembre de 2009 / Aceptación: 25 de septiembre de 2011 


\section{LOS DOS ENTIERROS DEL ARZOBISPO}

$\mathrm{F}$ rancisco Orozco y Jiménez, arzobispo de Guadalajara, murió el 18 de febrero de 1936 a causa de una infección que le laceró el hígado y le oscureció el corazón. Lo enterraron por primera vez el viernes 21 de febrero de 1936 en el Panteón de Belén. Casi seis años después -el lunes 16 de febrero de 1942 - sus restos se trasladaron del panteón a la Catedral de Guadalajara. Su primer funeral fue un evento público que rebasó todas las expectativas: cobró un colorido y dimensiones insospechadas y atrajo por curiosidad y por devoción a cientos de miles de personas. Los impacientes esperaron durante horas ante la casa donde lo velaban, los demás acompañaron los restos del arzobispo a la que se pensaba entonces sería su última morada. La ceremonia luctuosa tuvo lugar del 18 al 21 de febrero de 1936. Las tomas fotográficas y las crónicas de esos días muestran - y permiten observar- cómo los cientos de miles de personas

se agolparon por las calles y las aceras para acompañar, a paso lento, los restos mortales del arzobispo: primero de su casa al Sagrario Metropolitano, luego en el camino hacia la Catedral de Guadalajara y más tarde en la procesión hacia el Panteón de Belén. El cuerpo del arzobispo fue inhumado en la cripta familiar del arzobispo sucesor, José Garibi Rivera.

En contraste, durante su segundo funeral, los restos del arzobispo no contaron con la compañía de años atrás. Uno de los diarios de la ciudad anunció que sus restos se conducirían "en forma privada" (Las Noticias, 16 de febrero de 1942). La Arquidiócesis de Guadalajara, encabezada por José Garibi Rivera, reubicó los restos de Orozco y Jiménez en la Catedral para que ocupara un espacio de dignidad junto a sus ancestros: los célebres obispos y arzobispos que lo habían precedido. El traslado de los restos se enmarcó en la conmemoración del Cuarto Centenario de la Fundación de la Ciudad de Guadalajara, festejo en el que la Iglesia tapatía honró a sus "padres y antepasados"
(De la Cueva, 1942). Despaciosamente, una pesada carroza fúnebre condujo por las calles adoquinadas de Guadalajara los restos mortales de Orozco y Jiménez en sentido inverso al trayecto que habían recorrido seis años atrás. ¿Quién fue este hombre de la Iglesia que conmocionó con su muerte a la ciudad y a quien - en apariencia al menos- fueron olvidando los fieles católicos?

Francisco Orozco y Jiménez nació en Zamora, Michoacán, el 19 de noviembre de 1864, en el seno de una familia acaudalada. A los 12 años, junto a Luis, su hermano mayor, viajó a Roma para estudiar en el Colegio Pío Latinoamericano. ${ }^{1}$ A dicho colegio acudieron sobre todo jóvenes procedentes de Michoacán. Por ejemplo, José Mora y del Río, quien habría de convertirse en arzobispo de México, formó parte de un grupo de michoacanos que llegó a Roma con Orozco y Jiménez (O’Dogherty, 1998: 188). El joven Francisco permaneció en el Pío Latinoamericano de 1876 a 1888. Regresó a Zamora para ejercer como capellán del Templo de San Francisco y de la Hacienda de La Noria. Ocho años después se doctoró en sagrada teología, en la Pontificia Universidad de México (Dávila, 1977: 145). Orozco y Jiménez llegó a dominar el latín, el griego, el italiano, el francés, el inglés y el portugués. Toda su vida mantuvo una copiosa correspondencia pública y privada.

Para abandonar su ejercicio de simple capellán en Zamora, Orozco y Jiménez emigró a la ciudad de México. Ahí se convirtió en profesor del Colegio Clerical de San Joaquín y del Seminario Conciliar. El 30 de mayo de 1902, el Papa León XIII lo designó obispo de Chiapas, función que desempeñó hasta 1912. Este nombramiento, y más tarde el de arzobispo de Guadalajara, al parecer se debió a la influencia del grupo que formaron los egresados del Colegio Pío Latinoamericano a su regreso a México. Los "piolatinos” eran Francisco Plancarte y Navarrete, José

\footnotetext{
${ }^{1}$ En 1858, el Papa Pío IX fundó el Colegio Pío Latinoamericano. Tocó al arzobispo chileno Víctor Eyzaguirre encargarse del proyecto. Véase Medina (1979: 32).
} 
María Méndez, Teófilo García, Manuel Velázquez, José Mora y del Río, Francisco Orozco y Jiménez, José de Jesús Herrera y Piña, Mauro Navarro, Ramón Ibarra, Antonio Paredes, Leopoldo Ruiz y Flores, José Othón Núñez, Antonio Plancarte y Eulogio Gillow (O’Dogherty, 1998: 188). Ellos fundaron en 1896 la Pontificia Universidad de México (O’Dogherty, 1998: 182), donde se doctoró Orozco y Jiménez. Eulogio Gillow, nombrado arzobispo de Oaxaca, colocó a varios egresados del Pío Latinoamericano en las diócesis sufragáneas de su arquidiócesis. Gillow influyó además en los nombramientos que recibieron Martín Tritschler, Francisco Orozco y Jiménez y Francisco Bánegas Galván, en Yucatán, Chiapas y Tabasco, respectivamente (O’Dogherty, 1998: 183). En 1908, con José Mora y del Río como arzobispo de México, crecieron las oportunidades para que otros piolatinos ocuparan arquidiócesis de importancia, como las de Michoacán y Guadalajara (O’Dogherty, 1998: 192). Motivos insospechados llevaron al obispo de Chiapas a convertirse en arzobispo de la segunda de estas arquidiócesis.

En 1911, el gobierno civil de Chiapas, que apodó al obispo Orozco y Jiménez como "el Chamula", lo acusó de "sublevar a los indios de aquella región" (Barbosa, 1988: 115). Esto tras un conflicto que estalló después del cambio de sede de la capital de San Cristóbal a Tuxtla Gutiérrez. En 1912, bajo la administración de Flavio Guillén, nuevo gobernador de Chiapas, Orozco y Jiménez modificó su posición ante las autoridades. En reconocimiento a su postura, el gobernador lo invitó a oficiar la misa de su boda, planeada para el domingo 13 de octubre de 1912 en Tuxtla Gutiérrez. Los habitantes de Tuxtla, enterados de antemano de la presencia del obispo, se opusieron a que Orozco y Jiménez visitara la ciudad. Ante la posibilidad de que se desatara un conflicto, el gobernador celebró su boda en Chiapa de Corzo (Guillén, 2000: 31). Orozco y Jiménez casó al gobernador e inmediatamente después declaró a Tuxtla "en estado de entredicho" durante un año (Guillén, 2000: 32). El 14 de octubre, Orozco y Jiménez viajó a la ciudad de México, posiblemente a entrevistarse con el arzobispo de México. En diciembre de 1912, el Papa Pío XI — con la segura intercesión de José Mora y del Río- designó a Orozco y Jiménez arzobispo de Guadalajara, el quinto a la sazón, cargo que desempeñó entre 1913 y 1936. Durante los 23 años al frente de su arquidiócesis, se mostró intransigente ante las políticas anticlericales. Cobró fama por su celo para organizar a los católicos de su arquidiócesis en asociaciones, por su injerencia en las decisiones de la jerarquía eclesiástica nacional y por su supuesta participación, entre 1926 y 1929, en el levantamiento armado de los católicos antiagraristas, conocido como "la Cristiada".

En este artículo analizo cómo Francisco Orozco y Jiménez construyó su imagen pública y cómo fue conmemorada en sus primeros funerales. Retomaré las nociones de Peter Burke en torno a la fabricación de la imagen de un personaje como Luis XIV (Burke, 2003). Ataré las ideas de Burke a los postulados del sociólogo Erving Goffman -que exponen que los individuos, al "actuar" ante los demás, proyectan una imagen particular de sí mismos-y atenderé el concepto de tradición concebido por Eric Hobsbawm. Las fotografías son mi principal fuente de información. Aunque he tenido acceso a cientos de cartas del arzobispo, éstas se relacionan más con cuestiones políticas que personales, como si todavía persistiera el temor, entre unos cuantos, de revelar los sentimientos más íntimos de mi biografiado. Metodológicamente he decidido ver su imagen -la que él se construyó- como una ventana hacia el interior de su persona. De manera indirecta, sostengo que podemos aprender tanto de sus poses ante la cámara como de sus pasos ante la vida, de los que quedan apenas borrosas huellas en los archivos entre las cartas disponibles que dirigió a sus subordinados. ${ }^{2}$

\footnotetext{
${ }^{2}$ Las tomas que analicé provienen en su mayoría del acervo fotográfico del Archivo Histórico de la Arquidiócesis de Guadalajara (AHAG). Otras fotos que estudié se publicaron en libros a propósito de Orozco y Jiménez: los dos tomos de la biografía que escribió Vicente Camberos Vizcaíno (1966) y un volumen de la serie Apuntes para la historia de la Iglesia de J. Ignacio Dávila Garibi (1977).
} 


\section{La función de la imagen}

El "Rey Sol", nos dice Burke acerca de Luis XIV, fabricó su imagen en conjunción con un equipo de "colaboradores" del régimen. La imagen de Luis XIV podía apreciarse desde todas las expresiones artísticas: danza, teatro, literatura, historia, pintura, escultura y arquitectura. El monarca se rodeó de los mejores exponentes y ellos lo promocionaron e inmortalizaron en sus obras. La fabricación de la imagen del rey debió mucho a las medallas y las monedas que se fundieron y acuñaron durante su reinado. Burke afirma:

la función de la imagen no era, en términos generales, presentar una copia reconocible de los rasgos del rey o una fría descripción de sus acciones. Su objeto era, por el contrario, celebrar a Luis, glorificarlo, en otras palabras, persuadir de su grandeza a espectadores, oyentes y lectores. Para lograrlo, artistas y escritores aprovecharon una larga tradición de formas triunfales (Burke, 2003: 26).

Peter Burke analizó en conjunto las maneras en que se representó a Luis XIV y partió de su análisis para recuperar la imagen pública que en esa época (16431715) se tenía del soberano. Los actos protocolarios también contribuyeron a rodearlo de un halo de espectacularidad:

como la unción del rey en 1654 o su boda en 1660, y rituales recurrentes, como la imposición de manos a los enfermos para curarlos o la recepción de embajadores extranjeros, podían considerarse acontecimientos donde se utilizaban múltiples medios para representar la "imagen viviente" del rey (Burke, 2003: 25).

Luis XIV siempre fue percibido en una actitud de grandeza. La historia lo consagró con los objetos que mostraban su poderío: la armadura "romana o medieval" y el "manto real" ricamente adornado "con flores de lis y orlado de armiño". No faltaba la peluca: un artificio que le agregaba altura física, y

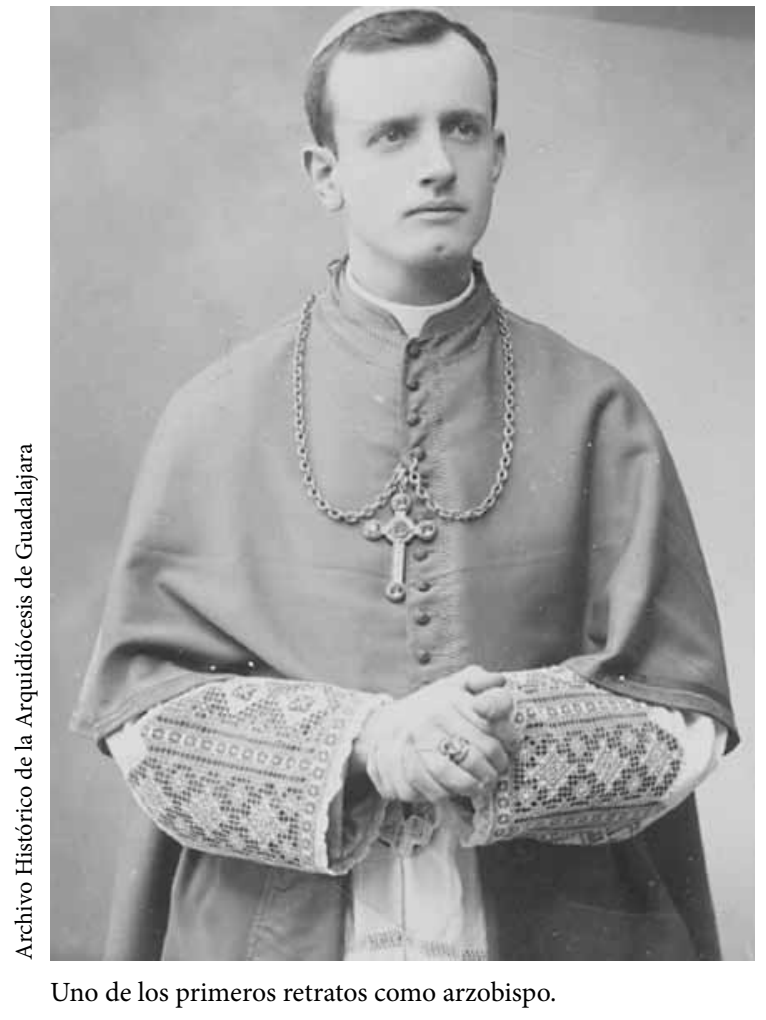

además llevaba "en la mano un orbe, un cetro o un bastón, todos ellos símbolos de mando" (Burke, 2003: 37). Parafraseando las diferencias que Eric Hobsbawm marca entre tradición y costumbre, la costumbre que seguía Luis XIV como rey era gobernar; "la 'tradición' (en este caso inventada)" era, aparte de usar una peluca, rodearse de otra "parafernalia formal", como empuñar en la mano todos los símbolos de mando mencionados (Hobsbawm, 2002: 9). En cuanto a su actitud corporal, Luis se mostraba en los retratos "por lo general impasible e inmóvil", postura que "simboliza el poder" (Burke, 2003: 37), pues la sonrisa "no se consideraba ademán adecuado para un rey de Francia" (Burke, 2003: 37-38). También convenía mostrar junto al soberano "diversas figuras en actitud de subordinación, como enemigos derrotados, cautivos acobardados, embajadores extranjeros inclinándose ante el rey" (Burke, 2003: 41). 
Pero no se crea que la imagen del rey Luis XIV la inventaron sus colaboradores: ésta descansaba en una mezcla de costumbre y tradición, es decir, en una forma ancestral - aunque en este caso hiperbólica- de caracterizar a los reyes franceses. La imagen de un rey francés se fincaba en la costumbre y la tradición heredadas de sus antepasados - lo que en estas páginas denomino "la construcción de su imagen pública", también hiperbólica-, y en el caso del arzobispo de Guadalajara se relaciona parcialmente con lo que la Iglesia católica establecía sobre el deber ser de la figura de los obispos. Tanto Luis XIV como Orozco y Jiménez, con el respaldo de las tradiciones y costumbres ancestrales, pero aumentando excesivamente sus facultades, crearon de sí mismos - con ayuda o sin ella- imágenes con las que fueran identificados fácilmente en su momento y en la posteridad.

Como el "Rey Sol", Francisco Orozco y Jiménez construyó de sí una imagen que acusaba pertenencia a la estructura eclesiástica, pero cultivó otra que transponía lo que hasta entonces encajaba en su perfil como jerarca de la Iglesia. Según el sociólogo Erving Goffman, la noción de "sí mismo" en la imagen que el individuo proyecta obliga a los otros a emplear el trato que corresponde con las personas de su tipo. Al rebasar serenamente las fronteras de lo esperado o lo permitido en cuanto a proyección, dentro de las reglas no escritas de los jerarcas de la Iglesia, Orozco y Jiménez esperaba sumisión entre sus coetáneos y veneración entre las generaciones venideras. Aunque Orozco y Jiménez seguía ciertas costumbres y tradiciones que correspondían a su envestidura, desplegaba un estilo particular que eclipsaba a los demás obispos. Como ejemplos basten su inconfundible y glamoroso modo de vestir, su distinguido porte y su manera de mostrarse ante la sociedad. Goffman señala que el individuo debe mostrar que realmente es lo que pretende ser. La persona "automáticamente presenta una exigencia moral a los otros [...]. Los otros descubren, entonces, que el individuo les ha informado acerca de lo que 'es' y de lo que ellos deberían ver en ese 'es"'

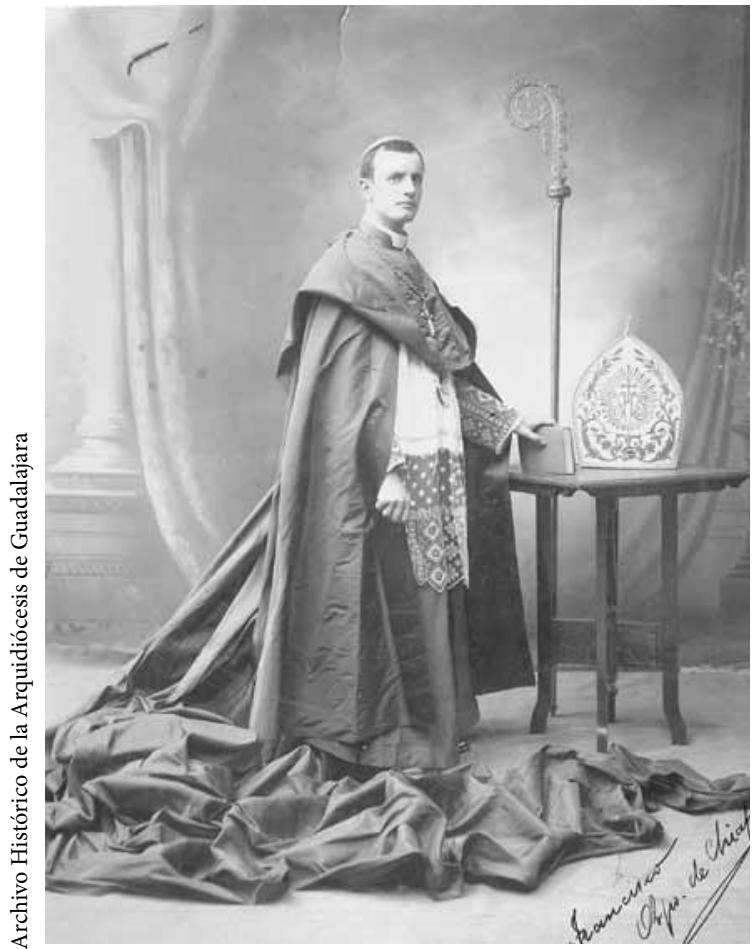

Obispo de Chiapas, 1902-1912.

(Goffman, 2004: 25). Con el paso del tiempo los tapatíos aprendieron qué era lo que su arzobispo quería que vieran en él y lo transmitieran a sus descendientes.

\section{Ocupación: arzobispo de Guadalajara}

Francisco Orozco y Jiménez tenía 48 años cuando llegó a la capital de Jalisco. Era un hombre maduro para la época, pero joven para la Iglesia. La fama de obispo "inquieto y levantisco" y de persona non grata con la que salió del obispado de Chiapas viajó antes que su persona, y los integrantes de la curia tapatía ya esperaban con desmayo el arribo de un “arrogante prelado" (Camberos, 1966, 1: 222, 224).

Desde antes de su arribo a Guadalajara, se sospechaba que Orozco y Jiménez era un arzobispo altivo. Una vez en la arquidiócesis, a través de su iglesia, 
circuló fotografías suyas de cuando recién se ordenó sacerdote. Su idea era documentar gráficamente y ante los ojos de los católicos que pese a su juventud dirigió con tenacidad - si bien durante un lapso corto- una diócesis tan extendida y compleja como la de Chiapas. Los vehículos con que buscaba confirmar esta aseveración fueron sus fotografías lozanas. La juventud del nuevo arzobispo encarnaba la metáfora del vigor y la robustez necesarios para dirigir la arquidiócesis de Guadalajara, una de las tres más importantes después de la de México, junto a la de Puebla y la de Morelia. Que uno de sus biógrafos lo describiera como dueño de un "porte dignísimo" y poseedor de la figura de "un auténtico príncipe lleno de majestad" (Camberos, 1966, 1: 224) puede atribuirse a una visión apologética, pero también nos habla de la percepción de su imagen por sus contemporáneos.

Para estudiar una fotografía el historiador debe interrogarse cuál era el "objetivo que con ella persiguiera su autor” (Burke, 2001: 22). Debe considerar que "el retrato es un género pictórico que, como tantos otros, está compuesto con arreglo a un sistema de convenciones que cambian muy lentamente a lo largo del tiempo" (Burke, 2001: 30). El rostro y el cuerpo de las personas retratadas, aunados a los objetos que aparecen a su alrededor, transmiten mensajes y significados particulares: están ahí porque refuerzan la imagen de los retratados (Burke, 2001: 30). Los individuos buscan su mejor pose y lucen sus mejores vestimentas para retratarse: se aseguran de que el ojo de la cámara capture esa particular representación (Burke, 2001: 31) y registre la imagen de sí mismos que aspiran perpetuar.

Desde el inicio de su gobierno eclesiástico, Orozco y Jiménez recalcó su estatus de jerarca de la Iglesia tapatía y completó esta imagen con la de un hombre de buena posición económica. Pronto se difundió en la capital de Jalisco que el arzobispo contaba con su propia fortuna personal y familiar. El estatus, si atendemos a la definición de Goffman, consiste en no ostentarlo como un bien material, sino en relacionarlo estrechamente con el comportamiento del individuo. Según Goffman, al destacar el individuo su estatus sigue "una pauta de conducta apropiada, coherente, embellecida y bien articulada" (Goffman, 2004: 86). Después de esparcidos los rumores sobre su fortuna, Orozco y Jiménez procedió de acuerdo con su posición como arzobispo, pero también en concordancia con la clase social de la que procedía.

En su retrato "oficial" como obispo de Chiapas (1902-1912), Orozco y Jiménez se muestra con sus vestimentas obispales. Una gran capa cae sobre el piso y enmarca su silueta. Su postura corporal es rígida y su rostro acusa seriedad. Gestos propios de una persona que detenta poder, dice Peter Burke. Contribuye a crear este efecto que Orozco y Jiménez esté de pie, así impone su figura de cuerpo entero. Objetos que simbolizan su autoridad lo flanquean. La composición en conjunto nos habla de un obispo que atenderá y atraerá a los feligreses, combatirá a los enemigos de la Iglesia y predicará la palabra de Dios. El retrato "oficial” de Orozco y Jiménez como arzobispo de Guadalajara guarda numerosas semejanzas con su retrato como obispo de Chiapas, pese a la distancia temporal de casi 12 años entre uno y otro. En su fotografía como arzobispo, Orozco y Jiménez está de pie, mira la cámara de frente y lleva una caudalosa capa que se desparrama por el piso. Su rostro proyecta gravedad, un signo de su "actuación" como patriarca. A sus espaldas se aprecia un altar con figuras religiosas. Este trasfondo que cobija al prelado alude a una Iglesia que lo respalda como institución. La composición abraza varios símbolos de potestad que refuerzan la autoridad de un arzobispo joven en una vieja diócesis, la de Guadalajara, creada en 1548 y distinguida como arquidiócesis en 1863.

Una segunda imagen de Orozco y Jiménez, ataviado con sus vestiduras arzobispales, data de alrededor de 1917, época en que permaneció oculto en algunos pueblos de su arquidiócesis, cuando el gobernador de Jalisco, Manuel M. Diéguez, implementó medidas 


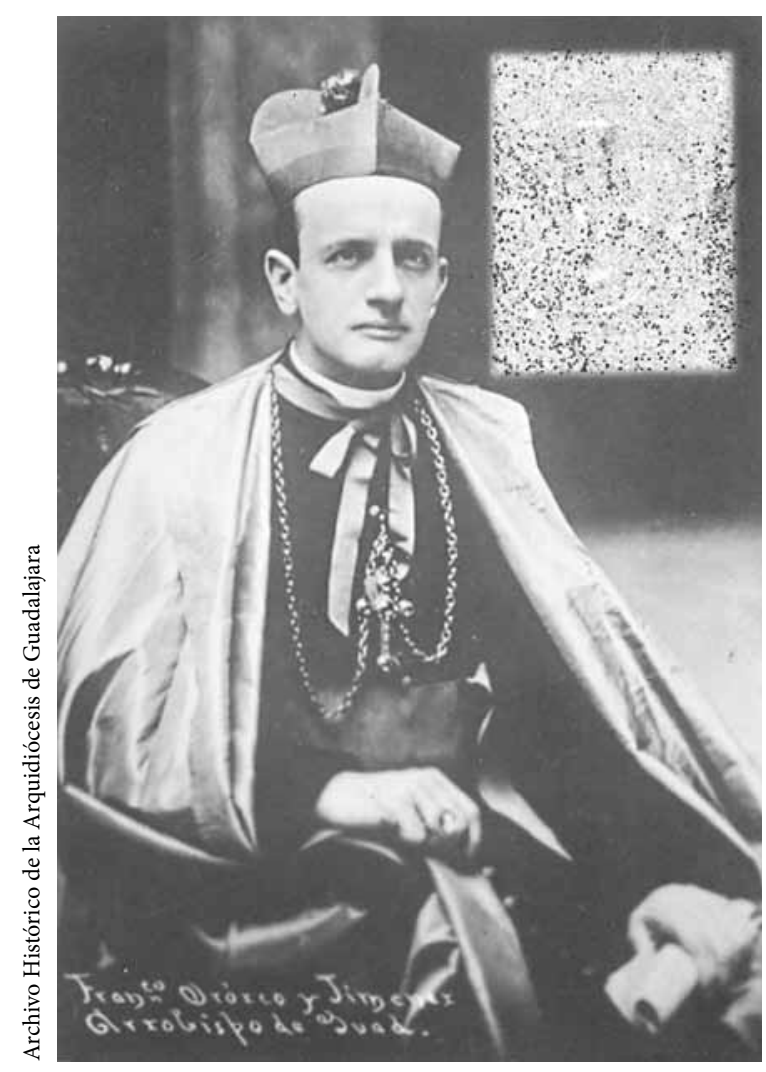

Arzobispo de Guadalajara, 1913-1936.

que, según el arzobispo, coartaban la libertad de su iglesia. Durante ese periodo, disfrazado, el arzobispo se escondió tras la espesura de una tupida barba. La toma - que remite a un escenario improvisado y a un retrato captado en la más absoluta discreciónes de pobre calidad. La amplia capa que lo engalanó en fotos anteriores está ausente en la estampa de un arzobispo barbado con sus vestimentas reglamentarias. Aunque la impureza de la foto impide observar su rostro con nitidez, se aprecia un gesto que traiciona cierta preocupación. Quizá porque en el fondo no aparecen elementos que aludan a la Iglesia como institución, el arzobispo porta la mitra y sostiene el báculo con la mano derecha, sin cargar la cruz pectoral. La imagen apunta a una Iglesia abatida y pinta a su representante bajo condiciones de penuria. Obviando las circunstancias fortuitas que lo rodean, el arzobispo - tomado su retrato en uno de sus escondites secretos- transmite un mensaje rotundo a sus fieles: detenta todavía en sus manos la autoridad eclesiástica.

\section{LA AUTOCONSTRUCCIÓN DE LA IMAGEN}

Todo indica que el arzobispo no contó — como Luis XIV en su momento- con un equipo de colaboradores para delinear su imagen, pero las fotografías, las cartas pastorales, las breves biografías que se publicaron tras su muerte y su particular labor como editor de obras de la Iglesia reforzaron la imagen visual del arzobispo. En su primera carta pastoral Orozco y Jiménez (1913) se presentó a sus diocesanos como deseaba que se le reconociera a partir de entonces: como un prelado que desempeñaría con energía su papel de "padre y pastor". Cuando difundió el programa que ejecutaría en su arquidiócesis, detalló lo que esperaba de sus feligreses, del clero y de sus más cercanos colaboradores. En esa primera carta el arzobispo señaló los puntos importantes de su quehacer arzobispal: la cuestión social, la predicación, la doctrina y la buena prensa en oposición a la "mala" prensa (Orozco y Jiménez, 1913: 10), cuatro aspectos básicos que guiarían su gobierno durante los 23 años siguientes. Rompiendo con la prudencia establecida como norma por sus antecesores, Orozco y Jiménez, desde el inicio, advirtió:

El prelado puede y debe a veces permitirse ciertos atrevimientos que a los menos avisados podrán parecer imprudencias: dejadle a él las responsabilidades y las consecuencias de semejantes actos; resguardad vuestras conciencias al amparo de la suya; y en cualquiera parte donde haya peligro él no tendrá reparo en exponerse por vosotros y aun en sustituirse a vosotros (Orozco y Jiménez, 1913: 11).

Además de mostrarse afecto a sacrificarse por sus fieles, Orozco y Jiménez pulió, de acuerdo con su jerarquía de arzobispo, su faceta como editor y 


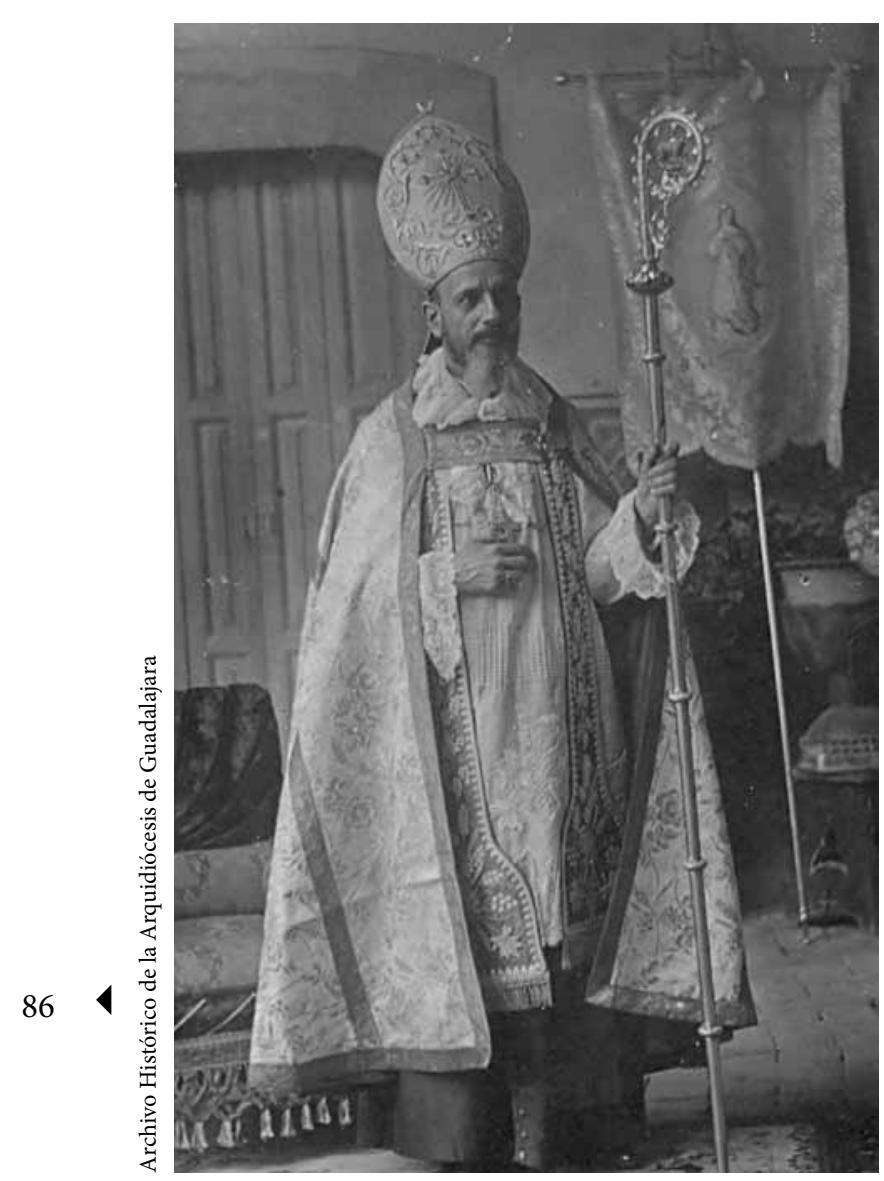

Alrededor de 1917-1918.

compilador, actividad que lo acercó a la historia. Rescató documentos raros, obras de historia y de religión, y métodos para leer y escribir. Este aspecto exaltó la imagen de un hombre instruido y preocupado por el pasado. ${ }^{3}$ Un hombre culto y arrojado, a quien los católicos tapatíos aprenderían a respetar. Como lo he expresado, tenía una faceta original cuando se presentaba ante los demás. ¿Pensaría más de uno que su prelado pecaba de atrevido e imprudente al portar las prendas que tanto le gustaba lucir?

\footnotetext{
${ }^{3}$ Entre los expedientes raros que Orozco y Jiménez rescató y publicó antologados posteriormente en dos tomos se encuentran los Documentos inéditos de la historia de la Iglesia de Chiapas (1999). Véase también Orozco y Jiménez (1903 y 1931).
}

La figura que Orozco y Jiménez proyectó a través de su persona arropada con las vestiduras arzobispales recuerda lo que Goffman describe como la "fachada personal", conformada por componentes intrínsecos al individuo, que éste exterioriza al actuarlos en el escenario de la realidad. Para que su actuación sea creíble, debe mostrar los símbolos de estatus que acreditan lo que pretende ser:

las insignias del cargo o rango, el vestido, el sexo, la edad y las características raciales, el tamaño y aspecto, el porte, las pautas de lenguaje, las expresiones faciales, los gestos corporales y otras características semejantes (Goffman, 2004: 35).

Los retratos del arzobispo - tomados en su mayoría en interiores- dejan ver una imagen oficial, dispuesta de antemano. En esos retratos el arzobispo adoptaba la postura de jerarca que se esperaba de él. La "parafernalia formal" de la que nos habla Hobsbawm, con la que Orozco y Jiménez se rodeaba - la capa, el palio, la mitra y el anillo pastoral-, fue el símbolo de estatus que el arzobispo gustaba mostrar, que su porte y garbo completaban. Mediante sus retratos, los feligreses y quienes no lo eran aprendieron a reconocer su figura. Muchas de las fotografías del arzobispo se pueden encontrar en su primera biografía (Dávila, 1913) y en el periódico católico El Regional, dirigido, en 1913, por el sacerdote Antonio Correa.

\section{Un arzobispo insumiso}

La imagen que se labró de sí Orozco y Jiménez se contrapuso a otra visión antípoda: la que el gobierno de Jalisco perfiló de él como arzobispo rebelde y cabecilla de bandidos. Goffman argumenta:

aunque, de mala gana, permitamos que ciertos símbolos de estatus establezcan el derecho de un actuante a un cierto tratamiento, siempre estamos listos a abalanzarnos sobre fallas de su armadura simbólica a fin de desacreditar sus pretensiones (Goffman, 2004: 70). 


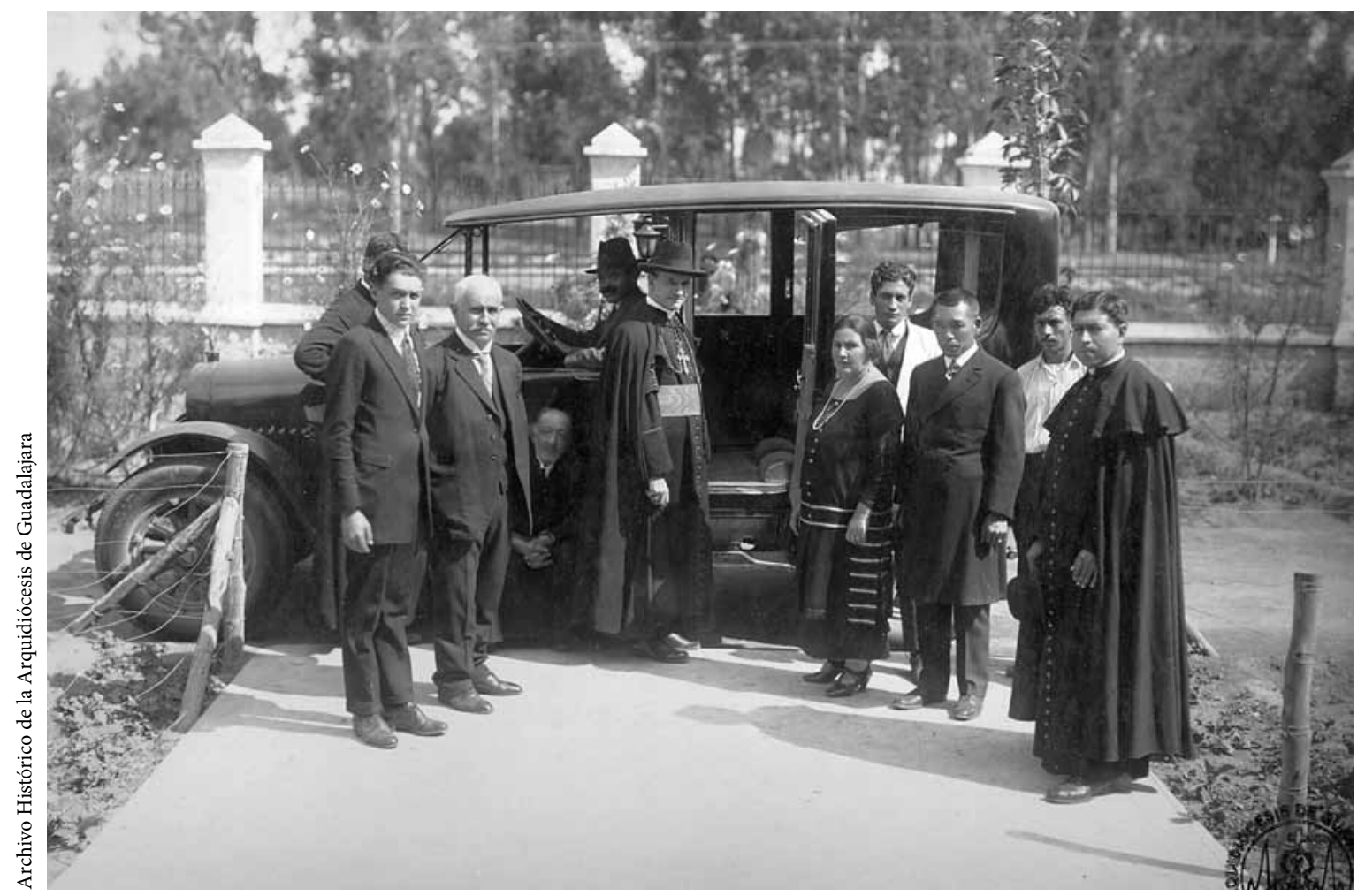

La construcción de la imagen.

Esto sucedió con la imagen del arzobispo. Uno de los prismas de su genio era su carácter incendiario - en opinión de sus contemporáneos- o modernizante, si se le observa en perspectiva. La imagen de sedicioso que las autoridades locales, y posteriormente las nacionales, le colgaron a Orozco y Jiménez se originó sin duda en el enfrentamiento que a su llegada como arzobispo de Guadalajara sostuvo con el entonces gobernador José López Portillo y Rojas. Cuando en una ocasión el gobernador prohibió que el arzobispo encabezara una peregrinación por las calles tapatías, Orozco y Jiménez lo desobedeció. El 15 de julio de 1914, Victoriano Huerta renunció a su puesto como presidente interino y fue sustituido por Francisco Carvajal. Durante el gobierno de este último, los constitucionalistas acusaron a los jerarcas de la Iglesia de amistarse con Huerta. Obispos y arzobispos, tras negar públicamente cualquier relación cordial con el exmandatario o su gobierno, se desterraron voluntariamente. ${ }^{4}$ En Jalisco, con los constitucionalistas, inició una época de inquietud para la Iglesia católica. El gobernador del estado, Manuel M. Diéguez - en el cargo a partir del miércoles 8 de julio de 1914- encarceló a muchos hombres de la Iglesia. A mediados de agosto de 1914, Orozco y Jiménez zarpó a La Habana por el puerto de Veracruz. De La Habana viajó a Santander,

\footnotetext{
${ }^{4}$ Mi búsqueda de correspondencia entre Huerta y los arzobispos durante la administración pública del primero en el Archivo Histórico del Arzobispado de la Ciudad de México no rindió fruto alguno. Esto, por supuesto, no significa que no existiera dicha correspondencia, porque posiblemente fluía a través de terceros desconocidos y, por tanto, difíciles de ubicar en cualquier archivo, en el caso supuesto de que sus relaciones hubieran dejado tras de sí algún rastro epistolar.
} 
Zaragoza y Barcelona y luego a Roma. Permaneció casi dos años hospedado en el Seminario Pío Latinoamericano. En tanto, Manuel M. Diéguez reglamentó el divorcio, cambió los nombres de calles y pueblos que ostentaran los de santos por otros que no lo fueran... En fin: expidió decretos que debilitaron la postura terrenal de la Iglesia. Mientras Diéguez implementaba sus políticas anticatólicas, Orozco y Jiménez, en ese su primer destierro, protegió su identidad bajo el seudónimo de Juan Rodríguez (Camberos, 1966, 1: 293).

Mientras tanto, el arzobispo de México, José Mora y del Río, al llegar a Nueva Orleáns expresó sus esperanzas de que Estados Unidos participara directamente en el conflicto en México e interviniera a favor de los católicos (Padilla, 2009: 48). A diferencia de Orozco y Jiménez, quien se guardaba de declarar en público su postura contra los carrancistas, el arzobispo de México no tenía empacho en declarar abiertamente su repudio a las diferentes facciones revolucionarias que desmem-

braban entonces a México. Preocupado por los miles de sacerdotes y monjas que se habían rezagado en México sin posibilidad de escape, el arzobispo admitió que era "inútil solicitar a Estados Unidos $o$ incluso [al] presidente Wilson que tomara acción inmediata". Todo parecía perdido: "Los carrancistas, villistas, orozquistas y otros cabecillas de bandidos", aclaró Mora y del Río, "exterminarían a todos aquellos sacerdotes y todas las hermanas de la fe que quedan antes de que un ejército estadounidense pudiera cruzar el Río Bravo". De nada valía solicitar "ayuda temporal" antes de que terminara la guerra europea y las naciones pudieran "tomar un esfuerzo conjunto en contra de los bárbaros que gobiernan ahora a México" (Boston Globe, 9 de marzo de 1915). Mientras Mora y del Río revelaba las atrocidades que ocurrían en México para inclinar la opinión pública en contra de los revolucionarios, otros arzobispos seguían los acontecimientos y estaban al acecho de lo que ocurriera. Pero ninguno de los representantes del gobierno se preocupaba por pedirles que retornaran a México.
Pasaron meses antes de que Orozco y Jiménez decidiera regresar de su destierro. En febrero de 1916, el arzobispo reveló sus propósitos de viajar a Guadalajara: era tiempo de reinsertarse en la estructura que le confería su cargo. Decidió no esperar el permiso de los constitucionalistas para entrar subrepticiamente a México. Si sus colaboradores lo consideraban conveniente, llegaría a su país vía Manzanillo, para luego establecerse en Nayarit durante un tiempo. ${ }^{5}$ Volvió a Guadalajara el 20 de noviembre de 1916. Pronto, y pese a sus cuidados por pasar inadvertido, disfrazado de campesino, su presencia y actividades llegaron a oídos del gobernador constitucionalista. El sábado 24 de febrero de 1917, Manuel M. Diéguez libró causa contra el arzobispo por el delito de "alta traición a la patria". Cuatro días más tarde, al recibir Orozco y Jiménez la noticia, se ocultó y permaneció escondido tres meses y medio (Orozco y Jiménez, 1918: 6).

Durante ese tiempo se murmuró entre los diplomáticos de Alemania y Estados Unidos que habían "capturado" a Orozco y Jiménez y al obispo de Zacatecas, Miguel de la Mora. ${ }^{6}$ En Washington, la supuesta e inminente ejecución de Miguel de la Mora y de Orozco y Jiménez, acusados de participar en un "complot villista", alarmó a los católicos. El embajador de Estados Unidos en México intervino ante Cándido Aguilar, secretario de Relaciones Exteriores, para evitar la ejecución de los prelados. Charles B. Barker, afirmó: "tengo instrucciones para hacer ver claramente a las autoridades del Gobierno de V. E. el efecto de repugnancia que

\footnotetext{
${ }^{5}$ AHAG, sección Gobierno, serie Obispos, caja 2, exp. 20, Francisco Orozco y Jiménez. Años 1912-1918, carta de Francisco Orozco y Jiménez a Miguel Cano, Roma, 12 de febrero de 1916.

${ }^{6}$ Miguel de la Mora pasó por una experiencia similar a la del arzobispo de Guadalajara: salió de Zacatecas en 1914 y durante dos años radicó en Chicago y en San Antonio. Regresó subrepticiamente a México en 1916. En enero de 1917, luego de una batalla en Zacatecas entre villistas y carrancistas, fue aprehendido por el bando carrancista y acusado de contribuir a la causa de Villa (Padilla, 2009: 83-84).
} 
causaría en las naciones civilizadas la ejecución de estos hombres". La Legación del Imperio Alemán, a su vez, pidió a Venustiano Carranza que rescindiera la sentencia de "pena de muerte" para Orozco y Jiménez y De la Mora. Basó su petición en "consideraciones relacionadas exclusivamente a la política alemana". ${ }^{8}$

Orozco y Jiménez, contrario a las noticias que recibieron los gobiernos estadounidense y alemán, no estaba preso. Tampoco participó en el "complot villista": continuó escondido en los pueblos de su arquidiócesis. ${ }^{9}$ Meses después de la supuesta condena a muerte, Orozco y Jiménez agregó su nombre a una protesta contra la Constitución que los obispos mexicanos firmaron, desde Estados Unidos, el sábado 24 de febrero de 1917. Además, tomó la pluma e instruyó a los católicos para que se opusieran a las medidas anticlericales de los constitucionalistas. La pastoral de Orozco y Jiménez leída el domingo 24 de junio de 1917 en ocho templos de su arquidiócesis provocó gran escándalo. El gobernador Diéguez acusó de sediciosos al arzobispo y a los sacerdotes que leyeron la carta. Seis párrocos fueron arrestados. El lunes 16 de julio se cerraron las puertas de la Catedral y de los templos de Mezquitán, el Santuario, San José, Mexicaltzingo, la Capilla de Jesús, San Francisco y El Carmen. Sólo 16 templos permanecieron abiertos en Guadalajara. En abril de 1918 continuaban clausurados seis templos en Guadalajara. El gobierno de Jalisco seguía en su actitud hostil contra la Iglesia: el sábado 8 de junio de 1918 publicó el Decreto 1913, que establecía que sólo un sacerdote podía ejercer por cada templo

\footnotetext{
${ }^{7}$ Archivo SRE, sección 17, caja 9, exp. 279, carta "confidencial" de Charles B. Barker, de la embajada de Estados Unidos de América, al general Cándido Aguilar, Secretario de Relaciones Exteriores del Gobierno de Facto de México, Ciudad de México, 22 de enero de 1917.

${ }^{8}$ Archivo sRe, sección 17, caja 9, exp. 279, carta "Particular y urgente" de la legación del Imperio Alemán al general Cándido Aguilar, Ciudad de México, 24 de enero de 1917.

${ }^{9}$ Que Orozco y Jiménez seguía oculto en su arquidiócesis lo demuestra la correspondencia resguardada en el Archivo Histórico de la Arquidiócesis de Guadalajara.
}

abierto y que únicamente un clérigo podía celebrar misa por cada 5000 habitantes. La imagen que el gobierno civil pinceló de Orozco y Jiménez, alrededor de 1918, fue la de un hombre intransigente, opuesto a las órdenes gubernamentales locales y nacionales. El retrato oficial del arzobispo se coloreó como el de un rebelde enemigo de las medidas del Estado y como el de un líder indiscutible de hombres sublevados.

Enterado el gobernador del estado de que el arzobispo se escondía en Lagos de Moreno, Jalisco, ordenó su arresto. Tocó al teniente coronel Leopoldo Ortiz Sevilla, jefe de la zona militar, detenerlo el viernes 5 de julio de 1918 a las 10:00 de la noche (El Informador, 11 de julio de 1918). Ortiz Sevilla "conferenció largamente" con el arzobispo y después lo llevó a la Jefatura de Armas, donde lo mantuvo vigilado pese a la multitud de feligreses que se aglomeró afuera del lugar. Por órdenes de Manuel M. Diéguez, Ortiz Sevilla condujo al arzobispo a la ciudad de Guadalajara. Posteriormente, el general César López de Lara lo trasladó a Ciudad Victoria, Tamaulipas. De dicho lugar, López de Lara lo remitió al puerto de Tampico, donde el arzobispo permaneció encarcelado en la comandancia de policía. Después fue transferido al cuartel del Batallón 50 de la Brigada "Acosta" (El Informador, 17 de julio de 1918). Orozco y Jiménez estuvo detenido en Tampico diez días. Allí esperó al primer buque que lo conduciría, por órdenes del presidente Venustiano Carranza, a Estados Unidos (El Informador, 11 de julio de 1918). El sábado 20 de julio de 1918, con su pasaporte en mano, Orozco y Jiménez "sin escolta, y acompañado únicamente de dos personas de su amistad, atravesó la frontera" (El Informador, 23 de julio de 1918). En Jalisco y debido a la creciente oposición de los católicos, el gobernador desautorizó el Decreto 1913, pero el viernes 26 de julio de 1918 implementó el Decreto 1927, con las mismas restricciones que el anterior. A su llegada a Texas, Orozco y Jiménez se entrevistó con un oficial de inteligencia del Departamento del Sur, Fort 
Sam Houston, Texas. Ante el oficial, el arzobispo habló abiertamente sobre la situación de México bajo el gobierno de Venustiano Carranza. Resaltó que "los hombres del clero y laicos son absolutamente incapaces de obtener justicia de las autoridades militares o civiles en el poder." ${ }^{10}$ Para el arzobispo, la salvación de México estaba en "la intervención por parte de Estados Unidos [sic] siguiendo las mismas líneas perseguidas en Cuba". Orozco y Jiménez declaró que no veía:

otra oportunidad que ésta, para la vecina República. Él declara que los grupos revolucionarios mexicanos, entre los cuales se encuentran muchos hombres buenos, muy fácilmente podrían resolver este problema ellos mismos si se les proporcionaran dinero, provisiones, armas y municiones (NA, MID). ${ }^{11}$

El arzobispo, como puede constatarse, se inclinaba por la intervención estadounidense en México y por el apoyo con armas y pertrechos a los individuos opuestos a Carranza. Transcribo otra parte que re-
Declara también [Orozco y Jiménez] que el gobierno actual es prácticamente impotente fuera de la ciudad de México, y que los cuarteles carrancistas se han estado sublevando y han asesinado a sus oficiales en varias partes de la república. Él afirma que el movimiento revolucionario [es decir, anticarrancista] es muy poderoso, pero que en el presente solamente carece de una oferta suficiente de provisiones y dinero para desalojar sin demora al gobierno actual. Él afirma que los grupos revolucionarios están ganando poder y mostrando una tendencia a unirse en contra de Carranza (NA, MID). ${ }^{12}$

\footnotetext{
${ }^{10}$ NA, MID, Cuartel General del Departamento del Sur, Oficina del oficial de inteligencia del departamento Fort Sam Houston, carta de Robert Scott Israel, primer subteniente, para el oficial de Inteligencia del Departamento del Sur, Fort Sam Houston, Houston, Texas, 3 de agosto de 1918.

${ }^{11}$ NA, MID, Cuartel General del Departamento del Sur, Oficina del oficial de inteligencia del departamento Fort Sam Houston, carta de Robert Scott Israel, primer subteniente, para el oficial de Inteligencia del Departamento del Sur, Fort Sam Houston, Houston, Texas, 3 de agosto de 1918.

${ }^{12}$ NA, MID, Cuartel General del Departamento del Sur, Oficina del oficial de inteligencia del departamento Fort Sam Houston,
}

Si bien la entrevista no llegó más allá que a servir de material para llenar un reporte oficial, las opiniones transcritas revelan una imagen nítida de la postura anticarrancista del arzobispo. Convencido de que poco cambiaría y de que Carranza estaba en el poder para permanecer en él - con todo y sus medidas anticlericales-, Orozco y Jiménez regresó a la capital de Jalisco el martes 14 octubre de 1919. Para la década de los años veinte, a la figura del arzobispo se agregaron algunos adjetivos: para Álvaro Obregón y su gobierno, el prelado era un hombre profundamente impulsivo, pero falto de la inteligencia que se le atribuía:

Hasta la lectura del documento que dirigió a usted el señor Francisco Orozco y Jiménez, yo lo tenía en el concepto de un hombre impulsivo, pero de alta potencialidad mental. Leídos los demás documentos he modificado mi juicio, confirmandolo primero únicamente, pues ellos están redactados en un tono como el que al impulsivismo del autor corresponde, pero nunca a una inteligencia como la que generalmente se atribuía a este alto prelado (Zuno, 1958: 45-46).

\section{¿Cabecilla cristero?}

A partir del otoño de 1926, cuando se alzaron los primeros católicos antiagraristas contra el gobierno de Plutarco Elías Calles (1924-1928), creció la fama de Orozco y Jiménez de rebelde e insurrecto. Periodistas y autoridades civiles convirtieron al arzobispo en paladín de invencibles - aunque no invisibles- ejércitos rebeldes, lo que remataba su imagen subversiva y lo involucraba con el movimiento armado de principio a fin. ${ }^{13}$ Durante los tres años de la guerra, Orozco y Jiménez permaneció en

carta de Robert Scott Israel, primer subteniente, para el oficial de Inteligencia del Departamento del Sur, Fort Sam Houston, Houston, Texas, 3 de agosto de 1918.

13 Por todo Jalisco circuló una hoja anónima que aseguraba: "Mientras el Gobierno arregla decorosamente las dificultades, el arzobispo Orozco y Jiménez asesina y quema vivos a quienes caen en su poder" (Camberos, 1966, 2: 263). 
un rincón apartado de su arquidiócesis, con pocos contactos con sus subordinados. ${ }^{14}$ Este hecho menoscabó su autoridad ante el clero y los fieles y debilitó su presencia frente a los demás obispos. En la cuestión de los arreglos que orquestaron Leopoldo Ruiz y Flores, arzobispo de Morelia, y Pascual Díaz y Barreto, obispo de Tabasco, a partir de al menos $1928,{ }^{15}$ Orozco y Jiménez permaneció al margen. Con retraso, el arzobispo se enteró de las pláticas de Ruiz y Díaz con el gobierno para solucionar el conflicto, ${ }^{16}$ lo que le impidió participar en las negociaciones o boicotearlas. ${ }^{17}$

\section{Una imagen agrietada}

Hasta aquí las dos imágenes contrastantes del arzobispo: la que él construyó y la que montaron de él los gobiernos y la prensa oficialista. Ambas maduraron y envejecieron por etapas. Por ejemplo, entre 1913 y 1916, sus primeras y deslumbrantes imágenes en Guadalajara retrataron a un arzobispo joven, enérgico e irreverente ante los gobiernos

\footnotetext{
${ }^{14}$ Pese a que se mantuvo alejado de los focos de cristeros rebeldes, se le siguió acusando de capitanear a los cristeros: "Se reportó ayer", comunicó el New York Times a sus lectores, "que el arzobispo [Orozco y Jiménez] encabezó una revuelta en el estado de Jalisco, pero el Departamento de Guerra declaró hoy que no tenía información oficial de que el prelado estuviera personalmente a cargo de cualquier levantamiento" (New York Times, 19 de enero de 1927). Un año más tarde John Cornyn del Chicago Daily Tribune informó que el "sacerdote guerrero", como se apodaba al arzobispo, era el "espíritu líder" que "guiaba huestes a la batalla contra las organizaciones más poderosas del ejército federal", y que el arzobispo inspiraba "a sus seguidores católicos a hechos de heroísmo" (Chicago Daily Tribune, 4 de enero de 1928).

${ }^{15}$ Para una discusión sobre los intentos y fracasos por llegar a un acuerdo temprano entre ciertos representantes de la Iglesia católica y el presidente de México en turno, véase Ortoll (1987), en especial el capítulo 2 .

${ }^{16}$ AHAM, Fondo Pascual Díaz y Barreto, caja 47, exp. 4, carta de Francisco Orozco y Jiménez a Sr. D. L. [¿Leopoldo Ruiz y Flores?], sin lugar, 2 de diciembre de 1928.

${ }^{17}$ AHAM, Fondo Pascual Díaz y Barreto, caja 47, exp. 4, carta de Francisco Orozco y Jiménez a Sr. D. L. [¿Leopoldo Ruiz y Flores?], sin lugar, 25 de abril de 1928.
}

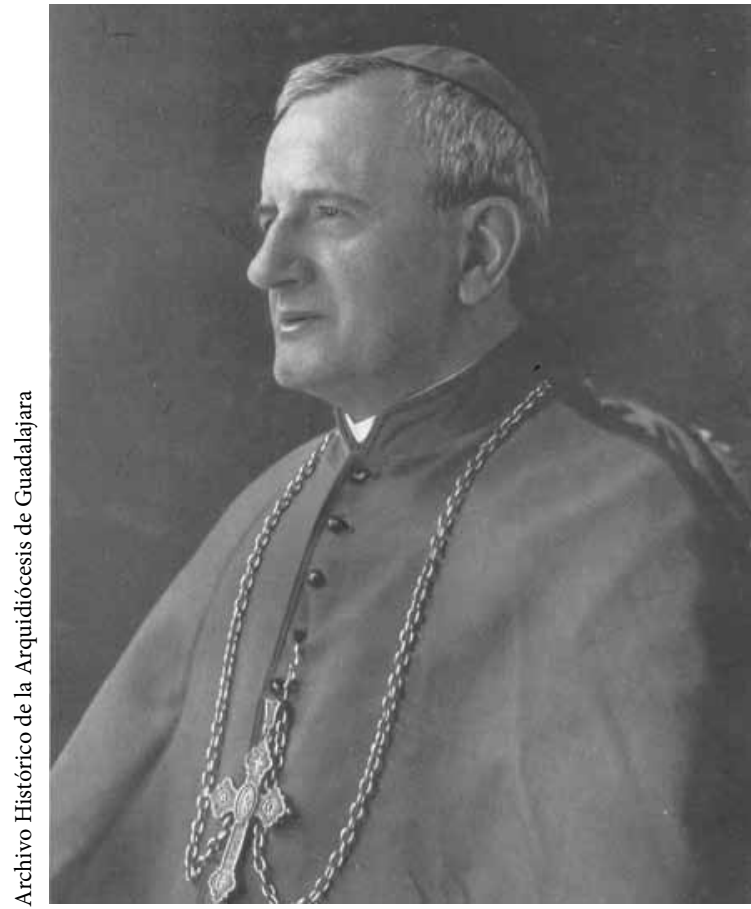

Moderado y cauteloso.

locales. Sobreviven pocas imágenes del arzobispo y sus correrías entre 1919 y 1929. Fue ésa una década que, sin embargo, permite concebir su figura, si se siguen de cerca sus actividades. A partir de 1919, Orozco y Jiménez creó y fortaleció asociaciones católicas laicas dentro de su arquidiócesis, pero no actuaba de motu proprio: su intensa gestión obedecía a una estrategia de la Iglesia en México de reforzar las organizaciones de católicos legos (Romero, 2006: 319). Durante estos años el gobierno anticlerical de José Guadalupe Zuno (1923-1926) restringió las acciones de la Iglesia en Jalisco, en particular las del arzobispo. Así, entre 1919 y 1925, la imagen que nos ofrecen los documentos de Orozco y Jiménez es la de un arzobispo activo que organiza a los católicos y se opone a las medidas anticatólicas del gobernador en turno.

A partir de 1926, cuando recrudeció el conflicto entre la Iglesia y el Estado, se retrató a Orozco y Jiménez de acuerdo con su ambigua intervención en 
la insurrección cristera. Para entonces la figura que perfiló el gobierno civil de él fue la de un líder armado - prácticamente con cananas cruzadas en el pecho- que distribuía propaganda y fomentaba la rebelión entre los católicos, apoyado por "varios frailes" y protegido por "numerosa gente armada." 18 Esta descripción era la de "jefe sanguinario y cruel" de los cristeros (Camberos, 1966, 2: 263). Las notas de la prensa de la época complementaron este retrato y difundieron la versión de que Orozco y Jiménez era el cabecilla indiscutible de los cristeros.

Los "arreglos" entre Emilio Portes Gil y los arzobispos Pascual Díaz y Barreto y Leopoldo Ruiz y Flores concluyeron oficialmente la Guerra Cristera. Como parte de esos arreglos, Díaz y Barreto informó a Orozco y Jiménez que debía presentarse ante el presidente de México. Portes Gil, quien supuestamente estaba convencido de que Orozco y Jiménez dirigía "a esos grupos inconscientes y aun [recorría] regiones del estado de Jalisco para animarlos y continuar su actitud belicosa", ${ }^{19}$ al encontrarse ante Desterrado, el arzobispo se dirigió a El Paso, Texas. Regresó en marzo de 1930.

Entre 1930 y 1932 el prelado envejeció. Ya no era el gallardo arzobispo de Guadalajara. Los retratos suyos que se conservan de esos años, de nuevo en el exilio, lo muestran cansado, rendido ante el deterioro de los años. Así definió en esa época el propio Orozco y Jiménez "sus particularidades personales": de "constitución física: delgada; estatura: Mts. 1.76; pelo: entrecano escaso; ojos: café claros; mentón: despejado; barba: afeitada; color: blanco; cejas:

\footnotetext{
${ }^{18}$ AJA, serie 0301, Ferreira Jesús M., legajo 3/4, inventario 157, carta de Jesús Ferreira a Joaquín Amaro, Guadalajara, 22 de septiembre de 1927.

${ }^{19}$ Aunque no he encontrado documentación que lo corrobore, es muy posible que el propio Pascual Díaz y Barreto haya sugerido al presidente que declarara lo citado para expulsar legítimamente del país al arzobispo de Guadalajara después de firmados los acuerdos: la presencia de Orozco y Jiménez resultaba mucho más peligrosa y potencialmente dañina para la Iglesia - que a partir de entonces dirigiría el exobispo de Tabasco- que para las autoridades constituidas (Camberos, 1966, 2: 263).
}

escasas; nariz: recta, grande; bigote: afeitado" (Camberos, 1966, 2: 357). Los rasgos del rostro del arzobispo, a sus 68 años, trazados con esmero, se unen a unos cuantos datos llanos que lo dibujan de cuerpo entero, despojándolo de sus vestimentas arzobispales. Su descripción recuerda el retrato de un hombre que envejecerá arrastrado ineludiblemente por el tiempo. Cuando regresó a México de su destierro, en 1934, el arzobispo ya evocaba la imagen de un anciano. Esta imagen de envejecimiento coincide con su nueva disposición pacificadora ante el gobierno local. ${ }^{20} \mathrm{La}$ imagen que los archivos resguardan representa a un arzobispo moderado y cauteloso: la cámara, que lo atrapa con el rostro de perfil, ya no deja ver la figura completa del arzobispo: sólo su busto. La mirada dubitativa de Orozco y Jiménez se pierde en la lejanía. El futuro de la Iglesia en la década de 1930 se antoja incierto.

Su más cercano colaborador, el obispo coadjutor José Garibi Rivera, utilizó la imagen del arzobispo viejo y enfermo. Al pedir al presidente Lázaro Cárdenas garantías para Orozco y Jiménez, Garibi Rivera lo representó como un "pobre anciano de más de 70 años, con una grave lesión orgánica y tan quebrantado por una serie de sufrimientos diversos", que era imposible que se pusiera "al frente de partidas de gente armada". ${ }^{21}$ Esa figura inofensiva que el obispo coadjutor dibujó de Orozco y Jiménez a finales de 1935 se trastocó dos meses después por la imagen de un cuerpo enfermo. El final se aproximaba.

\section{El ocaso de una imagen}

Justo el domingo 2 de febrero de 1936 Orozco y Jiménez entró en agonía. Sus feligreses recibieron la

\footnotetext{
${ }^{20}$ AHAG, sección Gobierno, serie Obispos, 1936-1943, exp. 27 caja 6, carta de Francisco Orozco y Jiménez al gobernador de Jalisco José María Cuéllar, Guadalajara, 15 de abril de 1930.

${ }^{21}$ AGN, grupo documental Lázaro Cárdenas del Río, vol. 914, exp. 547.3/86, carta abierta de José Garibi Rivera al presidente de la República, Lázaro Cárdenas, Guadalajara, 1 de noviembre de 1935.
} 


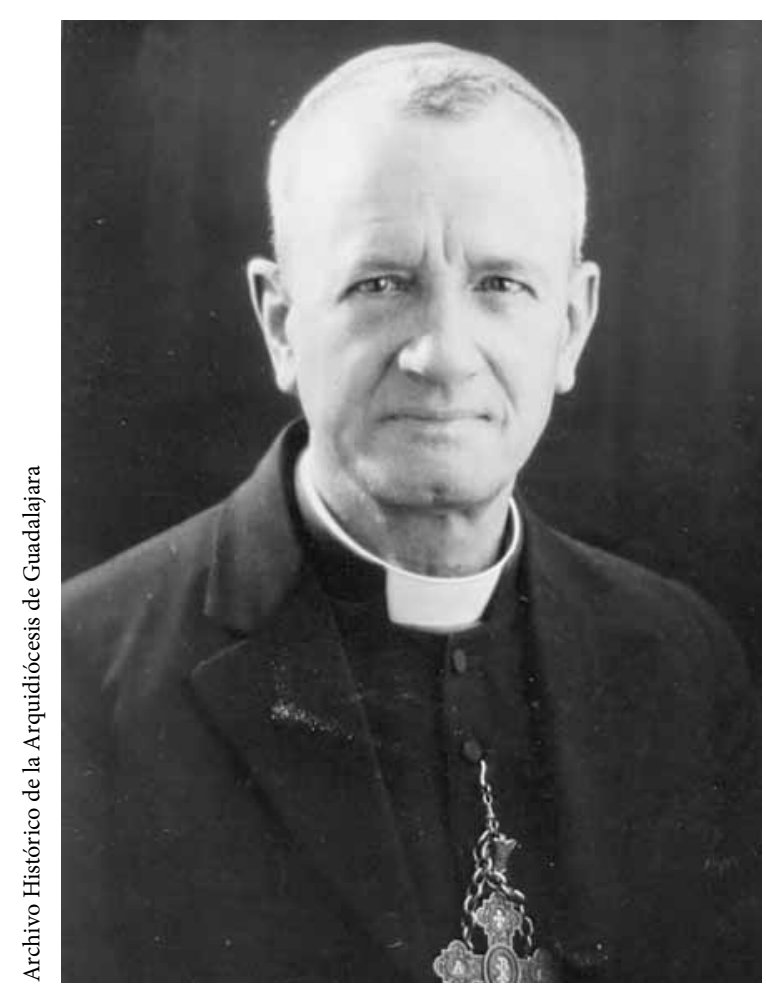

Los últimos años.

noticia dos semanas después a través de boletines médicos que aparecían en las puertas de los templos. Cito a Jacques Julliard, quien escribe sobre la muerte de un rey, pero sus palabras se aplican igual al caso del arzobispo de Guadalajara:

La enfermedad y la agonía, cuando se prolongan, dan la señal de la entrada del soberano a las capas bajas de la atmósfera humana. Bruscamente, sus órganos más íntimos se tornan el objeto de informaciones y de comentarios. He ahí ese poderoso, sometido a los caprichos de su corazón, de su intestino o de su vejiga, bajo la mirada de la muchedumbre. Cada parte facultativo, a pesar de los términos voluntariamente ocultos utilizados para atenuar el naturalismo de su objeto, es un recordatorio a la humildad; el acento puesto sobre tal o cual órgano marca el comienzo del despedazamiento (Julliard, 1999: 13).

Los padecimientos más íntimos de Francisco Orozco y Jiménez se tornaron públicos y los tapatíos discutieron a diario la condición de sus órganos. Sus médicos registraron cada uno de sus síntomas. El 18 de febrero de 1936, a las 18:45 horas, su fuerza o su corazón abandonaron a Francisco el arzobispo. La descripción de su semblante minutos después de morir recuerda el retrato del Orozco y Jiménez recién nombrado arzobispo de Guadalajara. Ni siquiera la muerte le arrebató esa imagen autoconstruida, como si el arzobispo recuperara su juventud antes de expirar. Así lo vio un escritor católico durante sus últimos días y los primeros minutos después de su muerte:

los destellos de su mirada avasalladora se armonizaban con la delicadeza de las líneas de su rostro, $[\ldots]$ su cuerpo recto y majestuoso fue invencible ante el dolor [...] su arrogante e imponente figura, no fue ajada por la mano del tiempo, ni desfigurada por la ancianidad, así tocó los dinteles de la eternidad, con el juvenil vigor que alentaba sus mejores días (Labor, núm. 28, 1936).

\section{CONCLUSIONES}

Tenemos dos imágenes contrastantes de Orozco y Jiménez: la construida por él mismo y la que labraron la prensa oficialista y los gobiernos civiles local y nacional. La imagen de Orozco y Jiménez que el Estado creó y a un tiempo creyó le sirvió para legitimar su captura y expulsarlo del país en varias ocasiones. Hasta el último momento de su vida, el arzobispo se empeñó en representar la figura que construyó de sí, en contraposición a la que le montaron los gobernantes en turno. Curiosamente, las imágenes más conocidas del arzobispo corresponden a dos etapas: la de su juventud y la de su madurez. ${ }^{22}$ En las páginas anteriores reconstruí la imagen

\footnotetext{
${ }^{22}$ Uno de mis dictaminadores afirma: "el Estado no creó una imagen de Orozco y Jiménez. Tenía información confidencial de sus actos, y de su conspiración [sic] ante el gobierno de Estados Unidos, al igual que otros arzobispos y obispos del país, a favor
} 
de Orozco y Jiménez a través de los testimonios de sus contemporáneos - fueran sus colaboradores, sus feligreses o autoridades civiles o militares- y destaqué cómo unos lo vieron y representaron como el arzobispo perseguido y otros como el arzobispo insumiso. Ambas imágenes contradictorias, que en su época escucharon y repitieron sus contemporáneos, persisten hasta nuestros días. En oposición a la representación que el arzobispo hizo de sí mismo, surgió una imagen antagónica que, con el paso del tiempo, perduró y completó la primera en la memoria de sus fieles y antiguos seguidores. En los primeros funerales del arzobispo, la figura que su sucesor José Garibi Rivera homenajeó del 18 al 22 de febrero de 1936 coincidió con la que Orozco y Jiménez construyó a lo largo de su vida. ${ }^{23}$ Garibi Rivera organizó los funerales en los que se rindieron honores al arzobispo y se aseguró de que los feligreses lo recordaran como el gran jerarca de la Iglesia que Orozco y Jiménez siempre se propuso

de Villa y en contra de Carranza”. Ya reproduje páginas arriba un documento de escasísima circulación que muestra que, en efecto, Orozco y Jiménez era anticarrancista. Pero sin pruebas a la mano, no puedo aseverar, que: a) el gobierno tuviera información confidencial sobre las actividades del arzobispo; b) que se declarara públicamente en contra de Carranza, y c) que conspirara junto a otros obispos ante Estados Unidos para que ese país invadiera a México. Sí mencionó la invasión como posibilidad afortunada, pero ante un militar subalterno en Texas, no ante las máximas autoridades estadounidenses en Washington. Caso distinto era el de José Mora y del Río, quien buscaba abiertamente el apoyo de Washington -incluso del presidente Woodrow Wilson- para proteger a los hombres de la Iglesia en México de los "bandidos" revolucionarios (Boston Globe, 9 de marzo de 1915).

${ }^{23}$ En estos momentos Orozco y Jiménez está en proceso de beatificación y es "siervo de Dios": el primer grado que recibe el candidato, después puede ser beatificado y más tarde canonizado. La imagen que promueve la causa de beatificación es la de "un hombre de profunda fe, fe que siempre defendió con valentía y a la vez con suma paciencia, perdonando siempre a los que lo calumniaban y perseguían, siempre tuvo la virtud de la fortaleza para defender la verdad". Como lo muestran estas palabras, la imagen del arzobispo de Guadalajara Francisco Orozco y Jiménez se transformó a tal grado que, en caso de que se le conceda la beatificación, será recordado y venerado como un "hombre de fe". Véase el tríptico "Siervo de Dios Excmo. y Rvmo. Sr. Dr. y Maestro D. Francisco Orozco y Jiménez" (Arzobispado de Guadalajara, Oficina de las Causas de Beatificación). ser. Seis años más tarde, más en control de la situación y de sus fieles, el nuevo arzobispo de Guadalajara exhumó a Orozco y Jiménez y a través de calles secundarias y silenciosas llevó a reposar sus restos para siempre bajo una pesada losa, sobre la que colocó la figura echada de un gran león de mármol.

\section{Referencias}

Barbosa Guzmán, Francisco, 1988, Jalisco desde la Revolución: La Iglesia y el gobierno civil, vol.6, Gobierno del Estado de Jalisco, Universidad de Guadalajara, Guadalajara, México.

Burke, Peter, 2003, La fabricación de Luis XIV, Nerea, San Sebastián.

- 2001, Visto y no visto. El uso de la imagen como documento histórico, Crítica, Barcelona.

Camberos Vizcaíno, Vicente, 1966, Francisco el Grande: Mons. Francisco Orozco y Jiménez, 2 vols., Jus, México.

Cornejo, José María, 1942, “Oración fúnebre pronunciada por el Sr. Cango. Honorario Dr. D. José María Cornejo, en las Solemnes Exequias celebradas con motivo de la traslación de los restos del Excmo. Sr. Orozco y Jiménez", en Boletín Eclesiástico de Guadalajara y de la Arquidiócesis de la Baja California, vol. 1, núm. 3, pp. 85-100.

Dávila Garibi, J. Ignacio, 1913, Datos biográficos del Ilmo. Y Rmo. Sr. Dr. y Mtro. D. Francisco Orozco y Jiménez, actual dignísimo metropolitano de Guadalajara y administrador apostólico de Chiapas, Tipografía El Regional, Guadalajara.

- 1924, Síntesis de la Acción Apostólica del Ilmo. Y Rvmo. Sr. Dr. y Mtro. D. Francisco Orozco y Jiménez como arzobispo de Guadalajara (1913-1924), Tipografía C. M. Sainz, Guadalajara.

— 1937, Labor científica y literaria del Exmo. Y Rvmo. Sr. Dr. y Mtro. Don Francisco Orozco y Jiménez, Tipografía Jaime, Guadalajara.

- 1977, Apuntes para la historia de la Iglesia de Guadalajara, vol. 5, Libros de México, México.

De la Cueva, Manuel, 1942, "Discurso pronunciado por el Sr. Pbro. Dr. D. Manuel de la Cueva, en la velada fúnebre con que la Iglesia de Guadalajara, honró la memoria del Excmo. Señor Arzobispo y Jiménez, y en él a todos los prelados de Guadalajara, difuntos", en Boletín Eclesiástico de Guadalajara y de la Baja California, vol. 1, núm. 3, pp. 78-84. 
Garibi Rivera, José, 1966, “Presentación”, en Vicente Camberos Vizcaíno, Francisco el Grande. Mons. Francisco Orozco y Jiménez, 2 vols., Jus, México, pp. 5-6.

Guillén, Diana, 2000, "Arreglos nupciales, iras santas y disputas regionales: apuntes para la microhistoria de Chiapas, 1911-1912", en Secuencia, núm. 47, pp. 5-38.

Goffman, Erving, 2004, La presentación de la persona en la vida cotidiana, Amorrortu, Buenos Aires.

Hobsbawm, Eric, 2002, "Introducción: la invención de la tradición", en Eric Hobsbawm y Terence Ranger (coords.), La invención de la tradición, Crítica, Barcelona, pp. 7-21.

Julliard, Jacques, 1999, “Introducción”, en Jacques Julliard (coord.), La mort du roi: essai d'ethnographie politique comparée, Gallimard, Mesnil-sur-l'Estrée, pp. 9-20.

Le Goff, Jacques y Nicolas Truong, 2005, Una historia del cuerpo en la Edad Media, Paidós, Barcelona.

Leonard, Irving A., 2004, La época barroca en el México colonial, Fondo de Cultura Económica, México.

Medina, Ascensio, Luis, 1979, Historia del Colegio Pío Latino Americano, Jus, México.

Meyer, Jean, 2000, “Dos hombres una situación”, en Letras Libres, año 2, núm. 23, pp. 52-58.

O'Dogherty, Laura, 1998, "El ascenso de una jerarquía eclesial intransigente, 1890-1914", en Manuel Ramos Medina (comp.), Historia de la Iglesia en el siglo XIX, El Colegio de México, México, pp. 179-198.

Orozco y Jiménez, Francisco (ed.), 1903, Colección de documentos relativos a la milagrosa imagen de la santísima Virgen de la Presentación llamada de Caridad que se venera en su templo de San Cristóbal L. C., mandolos copiar de los originales del archivo de esta Sta. Iglesia catedral y publicar el Ilmo. Y Rmo. Sr. Dr. D. Francisco Orozco y Jiménez, Obispo de Chiapas, Tipografía de la Sociedad Católica al cargo de Manuel J. Gutiérrez, San Cristóbal Las Casas.

— 1913, "Primera carta pastoral que el Ilmo. Y Rmo. Sr. Dr. D. Francisco Orozco y Jiménez arzobispo de Guadalajara dirige a sus diocesanos", en El Regional, Guadalajara, México.

— 1918, ¡Acerquémonos a Dios! Memorándum del Arzobispo de Guadalajara, sin editorial, San Juan de Los Lagos.

, 1929, Memorándum, Contreras Printing Company, Chicago.

- (ed.), 1931, Epistolae ad Sanctissimum in Chisto Patrem Pium Sextum Pont. Opt. Max. Ac Sacram rituum congregationem pro causa beatificationis et canonizationis Ven. Servi dei Antonii Margil a Jesu Missionarii apostolic ci ord. min. S. Francisci de Observantia I Terum Prelo mandavit Exc. Mus ac Rev. Mus D. P. Fanciscus
Orozco et Jimenez, Archiespiscopus Guadalaxarensis, Apud Loreto et Dieguez Succr, Guadalajara, México.

— 1932, Edicto del Exmo. Sr. Arzobispo Dr. Y Mtro. D. Francisco Orozco y Jiménez. Sobre su aprehensión y deportación al extranjero, sin editorial, San Francisco. , 1999, Documentos inéditos de la historia de la Iglesia de Chiapas, Consejo Estatal para la Cultura y las Artes de Chiapas, Tuxla Gutiérrez.

Ortoll, Servando, 1987, "Catholic Organizations in Mexico's National Politics and International Diplomacy, 1924-1942", tesis de doctorado, Columbia University, Nueva York.

Padilla Rangel, Yolanda, 2009, Los desterrados. Exiliados católicos de la Revolución Mexicana en Texas, 19141919, Universidad Autónoma de Aguascalientes, Aguascalientes.

Romero de Solís, José Miguel, 2006, El aguijón del espíritu. Historia contemporánea de la Iglesia en México (1892-1992), Instituto Mexicano de Doctrina Social Cristiana, El Colegio de Michoacán, Universidad de Colima, México.

Ruiz Medrano, J. (coord.), 1936, Homenaje a la memoria del Excmo. Sr. Dr. Mtro. D. Francisco Orozco y Jiménez arzobispo de Guadalajara, Imprenta Font, Guadalajara.

Sin autor (s. a.), 1936, "A la memoria del amado padre desaparecido, el Excmo. Y Rvdmo. Sr. Dr. y Maestro Don Francisco Orozco y Jiménez", en Labor, vol. 28, pp. 4-66.

Suárez, Hugo José, 2008, "Ensayo del análisis estructural de la fotografía cristera”, en Hugo José Suárez (coord.), El sentido y el método. Sociología de la cultura y análisis de contenido, El Colegio de Michoacán, Universidad Nacional Autónoma de México, México, pp. 281-297.

Tamayo, Jaime y Leticia Ruano, 1994, "Francisco Orozco y Jiménez 'Chamula': el arzobispo de la contrarrevolución”, en Carlos Martínez Assad (coord.), A Dios lo que es de Dios, Aguilar, México, pp. 229-254.

Valles, Patricia, 1994, "José Garibi Rivera: primer cardenal mexicano", en Carlos Martínez Assad (coord.), A Dios lo que es de Dios, Aguilar, México, pp. 267-285.

Zuno, José Guadalupe, 1958, Reminiscencias de una vi$d a$, Biblioteca de Autores Jaliscienses Modernos, Guadalajara.

\section{Fuentes hemerográficas}

“Los restos de Orozco y Jiménez a la catedral”, Las Noticias, 16 de febrero de 1942. 
"Sees Hope Only from Outside. Mexican Archbishop Tells of Hardships", Boston Globe, 9 de marzo de 1915.

"Cómo se llevó a cabo la aprehensión del Arzobispo Francisco Orozco y Jiménez", El Informador, 11 de julio de 1918, Guadalajara.

"Cómo llegó a Tampico el Arzobispo Orozco y Jiménez", El Informador, 17 de julio de 1918, Guadalajara.

"El Sr. Arzobispo Orozco y Jiménez se encuentra ya en territorio americano", El Informador, 23 de julio de 1918, Guadalajara.

"Mystery Envelops 2 Mexican Bishops", New York Times, 19 de enero de 1927.

"Fighting Bishop Foils Mexico's Rebel Hunters", Chicago Daily Tribune, 4 de enero de 1928.

"A la memoria del amado padre desaparecido, el Excmo. Y Rvdmo. Sr. Dr. y Maestro Don Francisco Orozco y Jiménez", Labor, vol. 28, 1936.

\section{Páginas electrónicas}

Diócesis de Orlando, en línea: <http://www.orlandodiocesis/org/sp/our-diócese/history/index.htm>, consultada el 21 de agosto de 2007.

\footnotetext{
"Vestimenta de obispos y arzobispos", en Aciprensa. Lo que todo católico necesita saber, en línea: <http://www. aciprensa.com/liturgia/vest-obispos.htm $>$, consultada el 20 de agosto de 2007.

\section{Archivos consultados}

Archivo de la Secretaría de Relaciones Exteriores (Archivo SRE), México, D. F.

Archivo General de la Nación (AGN), México, D. F.

Archivo Histórico de la Arquidiócesis de Guadalajara (AHAG), Guadalajara, Jalisco.

Archivo Histórico de la Arquidiócesis de México (AHAM), México, D. F.

Fideicomiso Archivos Plutarco Elías Calles y Fernando Torreblanca-Archivo Joaquín Amaro (AJA), México, D. F.

National Archives, Military Intelligence Division (NA, MID), College Park, Maryland. 